\title{
Effect of dietary protein content on animal production and blood metabolites of dairy cows during lactation
}

\author{
R. A. Law, ${ }^{\star 1}$ F. J. Young, ${ }^{\star}$ D. C. Patterson, ${ }^{\star}$ D. J. Kilpatrick, $†$ A. R. G. Wylie, $†$ and C. S. Mayne ${ }^{\star}$ \\ ${ }^{*}$ Agri-Food and Biosciences Institute, Agriculture Branch, Hillsborough, County Down, Northern Ireland BT26 6DR \\ †Agri-Food and Biosciences Institute, Newforge Lane, Belfast, Northern Ireland BT9 5PX
}

\begin{abstract}
Ninety autumn-calving Holstein dairy cows [45 primiparous and 45 multiparous (mean parity, 3.1)] were allocated to 1 of 3 dietary crude protein $(\mathrm{CP})$ concentrations: 173,144 , or $114 \mathrm{~g}$ of $\mathrm{CP} / \mathrm{kg}$ of $\mathrm{DM}$, from calving until d 150 of lactation. On d 151, half of the animals in each treatment were allocated an alternative dietary protein concentration. Half of the animals receiving $114 \mathrm{~g}$ of $\mathrm{CP} / \mathrm{kg}$ of $\mathrm{DM}$ went onto $144 \mathrm{~g}$ of $\mathrm{CP} /$ $\mathrm{kg}$ of DM; half of the animals receiving $144 \mathrm{~g}$ of $\mathrm{CP} /$ $\mathrm{kg}$ of DM went onto $173 \mathrm{~g}$ of $\mathrm{CP} / \mathrm{kg}$ of $\mathrm{DM}$; and half of the animals receiving $173 \mathrm{~g}$ of $\mathrm{CP} / \mathrm{kg}$ of $\mathrm{DM}$ went onto $144 \mathrm{~g}$ of $\mathrm{CP} / \mathrm{kg}$ of $\mathrm{DM}$, with the remaining animals staying on their original treatment. This resulted in 6 treatments in the mid to late lactation period: $114 / 114$, $144 / 144,173 / 173,114 / 144,144 / 173$, and $173 / 144 \mathrm{~g}$ of $\mathrm{CP} / \mathrm{kg}$ of DM. An increase in dietary $\mathrm{CP}$ concentration significantly increased milk, fat, and protein yield in early lactation (d 1 to 150). Dry matter intake was also increased with increased dietary protein concentration; however, this was not significant between 144 and 173 $\mathrm{g}$ of $\mathrm{CP} / \mathrm{kg}$ of DM. Increased dietary $\mathrm{CP}$ significantly increased plasma urea, albumin, and total protein concentrations but had no significant effect on NEFA, leptin, or IGF-1 concentrations. Decreasing the dietary CP concentration in mid-late lactation (d 151 to 305) from 173 to $144 \mathrm{~g} / \mathrm{kg}$ of DM had no significant effect on milk yield, dry matter intake, or milk fat and protein yield, compared with animals that remained on $173 \mathrm{~g}$ of $\mathrm{CP} / \mathrm{kg}$ of $\mathrm{DM}$ throughout lactation. Increasing dietary $\mathrm{CP}$ concentration from 144 to $173 \mathrm{~g} / \mathrm{kg}$ of DM significantly increased dry matter intake compared with animals that remained on the $144 \mathrm{~g}$ of $\mathrm{CP} / \mathrm{kg}$ of $\mathrm{DM}$ throughout lactation. There were no significant dietary treatment effects on live weight or body condition score change throughout the experiment. Results of this study indicate that high protein diets (up to $173 \mathrm{~g}$ of $\mathrm{CP} / \mathrm{kg}$ of DM) improved feed intake and animal performance
\end{abstract}

Received March 5, 2008

Accepted October 8, 2008.

${ }^{1}$ Corresponding author: Ryan.Law@afbini.gov.uk in early lactation (up to d 150), but thereafter, protein concentration can be reduced to $144 \mathrm{~g}$ of $\mathrm{CP} / \mathrm{kg}$ of DM with no detrimental effects on animal performance.

Key words: dietary protein, milk production, dry matter intake, energy balance

\section{INTRODUCTION}

The ever increasing requirement to maximize the economic efficiency of animal production has driven forward the intensification of farming systems. The exponential increase in the genetic potential for milk production of the dairy cow has resulted in an increase in dietary $\mathrm{CP}$ concentration of diets to ensure a sufficient supply of MP to achieve maximal milk production. At present, for high-yielding dairy cows a CP level of approximately $180 \mathrm{~g} / \mathrm{kg}$ of DM is commonly used in commercial diets (Kung, 2000). However, previous reports have suggested that increasing dietary protein concentration above $167 \mathrm{~g} / \mathrm{kg}$ of DM has no benefit in terms of yield of milk or milk components (Broderick, 2003). High dietary CP levels are positively associated with the degradation of protein in the rumen (increased ammonia concentrations) and have been shown to decrease the efficiency of nitrogen utilization for milk production (Broderick, 2003; Hristov et al., 2004). From an environmental perspective, 0.65 to 0.75 of nitrogen consumed is excreted via urine and feces (Chase, 1994; Yan et al., 2006). Yan et al. (2006) showed that nitrogen excretion in manure was highly correlated with dietary nitrogen intake, and hence a key mitigation strategy to reduce manure nitrogen output is to reduce dietary nitrogen concentrations. Furthermore, previous studies have shown that an over-supply of rumen degradable protein (relative to fermentable ME supply) will increase the diffusion of ammonia from the rumen to the portal blood supply and subsequently increase urea production (detoxification by-product) in the liver (Roseler, 1994). In addition, ureagenesis (conversion of absorbed ammonia into urea in the liver) is less efficient in cows with fatty liver (Strang et al., 1998), which will reduce the detoxification of ammonia in the blood. The toxicity of ammonia has been reported to inhibit vital 
processes such as gluconogenesis and the functionality of the tricarboxylic acid cycle (Rodriguez et al., 1997). Therefore, the balance between rumen degradable protein and fermentable carbohydrate is important in achieving an optimal ammonia concentration in the rumen.

The objective of this study was to investigate the effects of a range of dietary protein concentrations (120, 150 , and $180 \mathrm{~g} / \mathrm{kg}$ of DM) on animal production, energy metabolism, blood parameters, and nitrogen efficiency during early lactation ( 1 to $150 \mathrm{~d}$ ), and the subsequent effects of altering dietary protein concentration at $d$ 151 of lactation.

\section{MATERIALS AND METHODS}

\section{Animals and Housing}

Ninety Holstein-Friesian dairy cows [45 primiparous and 45 multiparous (mean parity 3.1)] were used in the experiment. Calving commenced on August 29 and ended on December 23. Following calving, animals were housed as a single unit in free stalls with concrete flooring. The cubicle to cow ratio was $\geq 1: 1$ at all times, meeting the recommendations set by FAWC (1997). Cubicles had a bed measurement of $2.20 \mathrm{~m}$ long and $1.25 \mathrm{~m}$ wide, were fitted with rubber mats, and were bedded with sawdust thrice weekly. Concrete passageway floors were scraped a minimum of 4 times daily using an automated system. Cows were milked twice daily at 0530 and $1630 \mathrm{~h}$, with cows traveling about $35 \mathrm{~m}$ to the milking parlor. Lights were left on in the buildings at all times.

\section{Experimental Design, Diets, and Feeding}

The experiment involved allocating 90 freshly calved Holstein-Friesian dairy animals to 3 dietary treatments that differed in overall $\mathrm{CP}$ levels, as formulated, in the complete diet (DM basis); 180, 150, and $120 \mathrm{~g} /$ $\mathrm{kg}$ of DM. At d 151 of lactation, half of the animals in each treatment were allocated (balanced for parity, milk yield, calving date and live weight) an alternative dietary $\mathrm{CP}$ concentration, while the remaining animals were maintained on their original diets. Half of the animals receiving $120 \mathrm{~g}$ of $\mathrm{CP} / \mathrm{kg}$ of DM went onto $150 \mathrm{~g}$ of $\mathrm{CP} / \mathrm{kg}$ of DM; half of the animals receiving $150 \mathrm{~g}$ of $\mathrm{CP} / \mathrm{kg}$ of $\mathrm{DM}$ went onto $180 \mathrm{~g}$ of $\mathrm{CP} / \mathrm{kg}$ of $\mathrm{DM}$; and half of the animals receiving $180 \mathrm{~g}$ of $\mathrm{CP} / \mathrm{kg}$ of DM went onto $150 \mathrm{~g}$ of $\mathrm{CP} / \mathrm{kg}$ of $\mathrm{DM}$. This resulted in 6 treatments ( 1 to $151 / 151$ to 305 DIM): 120/120, 150/150, 180/180, 120/150, 150/180, and 180/150. Primiparous animals were assigned in a balanced manner to treatments based on heifer rearing regime, calving date, and live weight. Multiparous animals were assigned to treatments according to parity, previous lactation milk yield, calving date, and live weight. The diet was presented as a TMR, and animals were fed between 1000 and 1100 $\mathrm{h}$ daily using a diet feeder. Animals had free access to water at all times. The concentrate to forage ratio (DM basis) was 0.55:0.45 for all diets. The forage component of the diet consisted of 0.60 grass silage and 0.40 maize silage (DM basis). Samples of grass and maize silage were taken weekly and analyzed using near infrared reflectance spectroscopy (Park et al., 1998), and twice weekly for measurement of nitrogen and ammonia nitrogen using methods outlined by Steen (1989). Two concentrates were formulated to contain 229 and 117 $\mathrm{g}$ of $\mathrm{CP} / \mathrm{kg}$ of $\mathrm{DM}$ to achieve target protein levels in the overall diets of 180 and $120 \mathrm{~g}$ of $\mathrm{CP} / \mathrm{kg}$ of DM, respectively. Diets containing $150 \mathrm{~g}$ of $\mathrm{CP} / \mathrm{kg}$ of $\mathrm{DM}$ were produced by complementing the forage component with equal amounts of concentrates containing 117 and $229 \mathrm{~g}$ of $\mathrm{CP} / \mathrm{kg}$ of DM. The energy and protein concentrations of individual ingredients were based on published values (AFRC, 1993), which were used in the initial formulation of the concentrate proportion of the diet as presented in Table 1. Concentrate samples were taken weekly during the experiment and analyzed for DM, ash, ADF, NDF, and nitrogen as described by Cushnahan and Gordon (1995). The TMR diets were offered ad libitum using feed boxes that were placed on a computer-recorded load cell system, with controlled access to the boxes using an electronic identification system. This enabled DMI of individual animals to be recorded continuously via automatic feeding gates (Calan gate feeder), from which a daily intake was calculated and then averaged on a weekly basis.

\section{Measurements}

Milk yields were recorded daily at each milking throughout the experiment. Milk composition (fat, protein, lactose, and SCC) was determined on a weekly basis from one consecutive a.m. and p.m. milking. Separate analysis was completed for a.m. and p.m. samples, and milk composition was calculated on the basis of recorded a.m. and p.m. milk yields. Milk composition was determined using an infrared milk analyzer.

Live weight and BCS (scale: 0 to 5; Edmonson et al., 1989) were recorded on a weekly basis and throughout lactation. Animals were blood sampled once weekly, between 0930 and $1130 \mathrm{~h}$, from the coccygeal vein using uncoated, heparin-coated, and fluoride oxalate-coated tubes (BD, Oxford, UK) from calving until d 100 of lactation, and then fortnightly thereafter. Plasma was recovered by centrifugation for analysis of glucose (fluoride oxalate tubes), total protein, albumin, globulin, BHBA, 
Table 1. Ingredient formulation of concentrates $(\mathrm{g} / \mathrm{kg}$ fresh) and energy and protein concentration (as formulated)

\begin{tabular}{lcc}
\hline Item & $\begin{array}{c}\text { Low protein } \\
(\mathrm{g} / \mathrm{kg}, \mathrm{DM})\end{array}$ & $\begin{array}{c}\text { High protein } \\
(\mathrm{g} / \mathrm{kg}, \mathrm{DM})\end{array}$ \\
\hline & 240 & 140 \\
Barley (milled) & 240 & 140 \\
Wheat (milled) & 163 & 94 \\
Unmolassed sugar beat pulp & 163 & 94 \\
Citrus pulp & 30 & 100 \\
Maize gluten feed & 80 & 100 \\
Distillers grain (maize) & 0 & 165 \\
Soybean meal (Hi-Pro) & 0 & 100 \\
Rape meal & 22 & 14 \\
Megalac ${ }^{1}$ & 3 & 3 \\
Trace minerals and vitamins & 4 & 4 \\
Salt & 12 & 0 \\
Dicalcium phosphate & 15 & 6 \\
Limestone (CaCO $\left.{ }_{3}\right)$ & 6 & 24 \\
Magnesium oxide & 24 & 13.1 \\
Molasses & 13.1 & 228.6 \\
ME (MJ/kg of DM) & 116.6 & 134.8 \\
CP (g/kg of DM) & 78.5 & 73.5 \\
Effective RDP (g/kg of DM) & 28.9 & 214.9 \\
Digestible undegradable protein & 310.6 &
\end{tabular}

${ }^{1}$ Volac Ltd., Orwell, Hertfordshire, UK.

NEFA, and urea (heparinized tubes), respectively, by clinical analyzer (Olympus UK Ltd., Middlesex, UK). Nonesterified fatty acid concentrations were determined using a standard kit (Wako Chemicals GmbH, Neuss, Germany). Uncoated tubes provided serum for leptin and IGF-1 RIA. Plasma and serum samples were stored at $-20^{\circ} \mathrm{C}$ until analyzed. Radioimmunoassays were balanced for dietary treatments, and parity and control samples were included in each assay.

Serum leptin concentrations were determined in samples taken from all animals in each of wk 2, 4, 6, 8, 10, 12,16 , and 20 . The primary anti-leptin antibody (OL-3) was raised in guinea pigs using recombinant ovine leptin kindly donated by A. Gertler (The Hebrew University of Jerusalem) and was included at a final dilution of $1: 160,000$ in each assay. Primary antiserum $(100 \mu \mathrm{L})$ and plasma $(100 \mu \mathrm{L})$ were incubated overnight $(20 \mathrm{~h})$ in a refrigerator after which was added $100 \mu \mathrm{L}(12,000$ to $15,000 \mathrm{cpm}$ ) of ${ }^{125}$ I-iodinated ovine leptin, prepared using iodogen (Perbio Science, Northumberland, UK). Tubes were then held for a further $24 \mathrm{~h}$ in a refrigerator before addition of $100 \mu \mathrm{L}$ of a cellulose-immobilized second antibody suspension (Sac-Cel anti-guinea pig IgG; IDS Ltd., Washington, Tyne on Wear, UK). Tubes were then left at room temperature for 20 min before addition of $1 \mathrm{~mL}$ of deionized water and centrifugation at $1,900 \times g$ for $20 \mathrm{~min}$. Following centrifugation, supernatant was removed, and radioactivity in each pellet was counted using a Cobra ll gamma counter (Packard Canberra, Reading, UK).
Serum IGF-1 concentrations were determined in samples taken, in wk 2, 6, 10, 16 and 20, from 4 multiparous and 4 primiparous animals, randomly selected from each of the 3 dietary treatments. Insulin-like growth factor-1 binding proteins were removed by acid-ethanol cryo-precipitation (Wylie et al., 1997) before analysis for free IGF-1. The primary antibody (AFP 4892898) was rabbit anti-human somatomedin C (a gift from A. Parlow of the US National Hormone and Pituitary Program, Torrance, CA), used at a final dilution of 1:400,000. Human recombinant IGF-1 purchased from NIBSC (National Institute for Biological Standards and Control, Potters Bar, Hertfordshire, UK) was used as the standard, and the label was ${ }^{125} \mathrm{I}$-human recombinant IGF-1 (Amersham International, Buckinghamshire, UK) included at 12,000 to $15,000 \mathrm{cpm}$ per tube. Bound IGF-1 label was recovered by addition of a second antibody (goat anti-rabbit IgG, Sigma Chemical Co, Poole, UK) followed by precipitation with polyethylene glycol succinate $(6 \% \mathrm{wt} / \mathrm{vol}$ solution). After centrifugation and removal of supernatant, pellets were counted using a Cobra II gamma counter. Blood samples were not analyzed for leptin and IGF-1 from 151 to 305 DIM.

\section{Calculation of Energy Balance}

The average daily energy balance for each animal was calculated each week of lactation using the equations described by Thomas (2004) \{energy balance $=\mathrm{ME}$ intake $-\mathrm{ME}$ requirement $\left[-10+\left(\mathrm{ME}_{\text {preg }}+\mathrm{ME}_{\text {maintmilk }}\right.\right.$ $\left.\left.\left.\times \mathrm{Lwt}^{0.75}\right)\right]+\left[(0.0013 \times \mathrm{Lwt}) / \mathrm{K}_{\mathrm{m}}\right)\right] ; \mathrm{K}_{\mathrm{m}}$, efficiency of energy use for maintenance $[0.35 \times(\mathrm{ME} / \mathrm{GE})+0.503]$. Daily milk yield, daily DMI, weekly milk composition, weekly live weight, and feed composition data were used in the calculations. The ME contents of grass and maize silage were obtained on a weekly basis using near infrared reflectance spectroscopy (Park et al., 1998), and $\mathrm{ME}$ contents of the concentrate were as formulated. Missing values were estimated from the week before and the week after missing data. Less than $2 \%$ of the data were missing.

\section{Statistical Analysis}

A repeated measures approach using the residual maximum likelihood procedure available in GenStat (Payne et al., 1993) was used to analyze the data set. The model fitted fixed effects for parity, dietary protein treatment, and stage of lactation (weeks from calving) for each parameter. The model included all 2-level interactions between these variables. Additional orthogonal contrasts were calculated for linear and quadratic effects of treatments from 1 to 150 DIM. There was 
Table 2. Composition of TMR as fed, indicating DM, CP, and ME contents

\begin{tabular}{|c|c|c|c|c|c|c|c|c|c|}
\hline \multirow[b]{2}{*}{ Item } & \multicolumn{9}{|c|}{ Target $\mathrm{CP}$ concentration $(\mathrm{g} / \mathrm{kg}$ of $\mathrm{DM})$} \\
\hline & Concentrate & $\begin{array}{l}\text { Grass } \\
\text { silage }\end{array}$ & $\begin{array}{l}\text { Maize } \\
\text { silage }\end{array}$ & Concentrate & $\begin{array}{l}\text { Grass } \\
\text { silage }\end{array}$ & $\begin{array}{l}\text { Maize } \\
\text { silage }\end{array}$ & Concentrate & $\begin{array}{l}\text { Grass } \\
\text { silage }\end{array}$ & $\begin{array}{l}\text { Maize } \\
\text { silage }\end{array}$ \\
\hline Proportion in diet & 0.55 & 0.27 & 0.18 & 0.55 & 0.27 & 0.18 & 0.55 & 0.27 & 0.18 \\
\hline DM content $(\mathrm{g} / \mathrm{kg})$ & 870 & 343 & 266 & 870 & 343 & 266 & 870 & 343 & 266 \\
\hline Total ME $(\mathrm{MJ} / \mathrm{kg}$ of $\mathrm{DM})$ & & 12.4 & & & 12.4 & & & 12.4 & \\
\hline Total CP $(\mathrm{g} / \mathrm{kg}$ of $\mathrm{DM})$ & & 173 & & & 144 & & & 114 & \\
\hline $\mathrm{ERDP}^{1}(\mathrm{~g} / \mathrm{kg}$ of DM $)$ & & 112.4 & & & 94.5 & & & 75.5 & \\
\hline $\mathrm{DUP}^{1}(\mathrm{~g} / \mathrm{kg}$ of $\mathrm{DM})$ & & 62.6 & & & 48.2 & & & 34.7 & \\
\hline
\end{tabular}

${ }^{1} \mathrm{ERDP}=$ effective RDP; DUP $=$ digestible undegradable protein.

no significant effect of dietary treatment on condition score change or live weight over the first 3 wk of lactation. Therefore, the deviation from the mean of these 2 variables, in multi- and primiparous animals during this period, was used as a covariate. Due to the design of this experiment, data were analyzed in 3 parts: 1 to 150 DIM, 151 to 305 DIM, and 1 to 305 DIM. An additional covariate was included in the analysis of data from 151 to 305 DIM: the difference between the mean of the variable in question from 135 to 150 DIM for each animal, and the overall mean of the same variable from animals within the same treatment from 135 to 150 DIM.

\section{RESULTS}

Table 2 illustrates the composition (as fed) of diets targeted to contain 120, 150 and $180 \mathrm{~g}$ of $\mathrm{CP} / \mathrm{kg}$ of DM. Actual values were 114, 144, and $173 \mathrm{~g}$ of $\mathrm{CP} /$ $\mathrm{kg}$ of DM respectively. All diets were isoenergetic. The effective rumen degradable protein $[\mathbf{e R D P}$, estimated using Feed into Milk (Thomas, 2004)] to digestible undegradable protein (DUP) ratios for diets containing 114,144 , and $173 \mathrm{~g}$ of $\mathrm{CP} / \mathrm{kg}$ of $\mathrm{DM}$ were 2.17 , 1.96 , and 1.79 , respectively [Feedbyte (Feed into Milk; Thomas, 2004)].

\section{Production Responses to Dietary Protein in Early and Mid Lactation (1 to 150 DIM)}

Dietary protein concentration effects on DMI, ME intake, milk yield, milk constituents (fat, protein, and lactose), constituent yields (fat and protein), and milk energy output are presented in Table 3. Increased dietary protein concentration significantly $(P<0.001)$ increased milk yield, milk protein concentration, total milk fat yield, total milk protein yield, and milk energy output. Increasing dietary protein concentration from 114 to $144 / 173 \mathrm{~g} / \mathrm{kg}$ of DM significantly increased DMI $(P<0.001)$ and decreased milk fat concentration $(P$ $<0.05)$. There was no significant $(P>0.05)$ difference in DMI or milk fat concentration between animals receiving 144 and $173 \mathrm{~g}$ of $\mathrm{CP} / \mathrm{kg}$ of DM. However, orthogonal contrasts for linear and quadratic effects suggest that the relationship between dietary protein concentration and DMI, and milk fat concentrations is linear $(P<0.001$ and $P<0.05$, respectively).

During the first $150 \mathrm{~d}$ of lactation, an increase in dietary protein content significantly $(P<0.001)$ increased the average daily ME requirement (Table 4 ). Increasing dietary protein concentration from 114 to $144 / 173 \mathrm{~g} / \mathrm{kg}$ of DM significantly increased ME intake and live weight. There was no significant difference in ME intake or live weight of animals between 144 and $173 \mathrm{~g}$ of $\mathrm{CP} / \mathrm{kg}$ of DM. Orthogonal contrasts for linear and quadratic effects suggest that the relationship between dietary protein concentration and live weight is curvilinear [significant $(P<0.01)$ linear and quadratic effects]. Increasing dietary protein concentration from 114 to $173 \mathrm{~g} / \mathrm{kg}$ of DM significantly $(P<0.001)$ decreased daily energy balance. However, there was no significant difference in daily energy balance between animals on $144 \mathrm{~g}$ of $\mathrm{CP} / \mathrm{kg}$ of $\mathrm{DM}$ and those on 114 and $173 \mathrm{~g}$ of $\mathrm{CP} / \mathrm{kg}$ of DM. Increasing dietary protein concentration from 114/144 to $173 \mathrm{~g} / \mathrm{kg}$ of DM significantly decreased cumulative energy balance. There was no significant effect of dietary protein concentration on the change in live weight or BCS over the first 150 DIM. There was a significant $(P<0.05)$ effect of dietary protein concentration on the interval to energy nadir (cumulative energy balance at lowest point). Dietary protein concentrations of 114,144 , and $173 \mathrm{~g} / \mathrm{kg}$ of DM produced intervals to energy nadir of $7.8,10.8$, and 14.8 wk $(\mathrm{SED}=2.61)$, respectively. 
Table 3. Effects of dietary protein concentration on DMI, milk yield, milk constituents (fat, protein, and lactose), and constituent yields (fat and protein) of animals in early and mid lactation (1 to $150 \mathrm{~d}$ )

\begin{tabular}{|c|c|c|c|c|c|c|c|}
\hline Item & \multicolumn{3}{|c|}{ Dietary CP concentration (g/kg of DM) } & $\mathrm{SED}^{1}$ & $P$-value & \multicolumn{2}{|c|}{ Contrast } \\
\hline DMI $(\mathrm{kg} / \mathrm{d})$ & $16.5^{\mathrm{b}}$ & $18.0^{\mathrm{a}}$ & $18.6^{\mathrm{a}}$ & 0.35 & $* * *$ & $* * *$ & NS \\
\hline \multicolumn{8}{|l|}{ Milk constituents $(\mathrm{g} / \mathrm{kg})$} \\
\hline Fat & $42.0^{\mathrm{a}}$ & $38.3^{\mathrm{b}}$ & $38.1^{\mathrm{b}}$ & 1.40 & $*$ & $*$ & NS \\
\hline Protein & 31.4 & 32.3 & 32.4 & 0.61 & NS & NS & NS \\
\hline Fat & $1.07^{\mathrm{c}}$ & $1.21^{\mathrm{b}}$ & $1.35^{\mathrm{a}}$ & 0.058 & $* * *$ & $* * *$ & NS \\
\hline Protein & $0.80^{c}$ & $1.03^{\mathrm{b}}$ & $1.15^{\mathrm{a}}$ & 0.031 & $* * *$ & $* * *$ & $*$ \\
\hline Fat + protein & $2.15^{\mathrm{c}}$ & $2.41^{\mathrm{b}}$ & $2.70^{\mathrm{a}}$ & 0.115 & $* * *$ & $* * *$ & NS \\
\hline Milk energy output (MJ/d) & $80.4^{\mathrm{c}}$ & $96.2^{\mathrm{b}}$ & $107.2^{\mathrm{a}}$ & 3.52 & $* * *$ & $* * *$ & NS \\
\hline
\end{tabular}

${ }^{\mathrm{a}-\mathrm{c}}$ Values within a row with no common superscript differ $(P<0.05)$.

${ }^{1} \mathrm{SED}=$ standard error of the difference.

NS, $P>0.05 ; * P<0.05 ; * * * P<0.001$.

An increase in the dietary protein concentration significantly $(P<0.001)$ reduced the efficiency of nitrogen use for milk production (Table 5). From 1 to 150 DIM animals receiving $114 \mathrm{~g}$ of $\mathrm{CP} / \mathrm{kg}$ of $\mathrm{DM}$ had a nitrogen efficiency of 0.423 in comparison with 0.350 in animals receiving $173 \mathrm{~g}$ of $\mathrm{CP} / \mathrm{kg}$ of $\mathrm{DM}$.

\section{Blood Responses to Dietary Protein in Early and Mid Lactation (1 to 150 DIM)}

The effects of dietary protein concentration on blood parameters are presented in Table 6. An increase in dietary protein concentration significantly increased plasma urea $(P<0.001)$, total protein $(P<0.001)$ and albumin $(P<0.001)$ concentrations, and decreased plasma BHBA $(P<0.001)$ concentrations. An orthogonal contrast for linear and quadratic effects identified a curvilinear relationship between urea and dietary $\mathrm{CP}$ concentration [significant linear $(P<0.001)$ and qua- dratic trends $(P<0.01)]$. There was no significant $(P$ $>0.05$ ) effect of dietary protein concentration on serum IGF-1, leptin, plasma glucose, globulin, or NEFA concentrations.

Significant effects of parity were also realized for blood parameters. Primiparous animals had significantly less albumin (32.3 vs. $33.2 ; P<0.05)$, total protein $(76.4$ vs. $78.7 ; P<0.01)$, and urea concentrations $(2.70$ vs. $2.95 ; P<0.01)$ than multiparous animals.

\section{Dietary Protein Adjustment at d 151 of Lactation}

The effects of adjusting dietary protein concentration at d 151 of lactation on production parameters are presented in Tables 7 and 8. From d 151 to 305 of lactation, increasing dietary protein concentration from 114 to $144 \mathrm{~g} / \mathrm{kg}$ of DM significantly increased DMI $(P<$ $0.001)$, ME intake $(P<0.001)$, milk yield $(P<0.001)$, milk fat yield $(P<0.001)$, milk protein yield $(P<$

Table 4. Effects of dietary protein concentration on live weight, BCS, and body energy status of animals in early and mid lactation (1 to 150 d)

\begin{tabular}{|c|c|c|c|c|c|c|c|}
\hline \multirow[b]{2}{*}{ Item } & \multicolumn{3}{|c|}{ Dietary CP concentration (g/kg of DM) } & \multirow[b]{2}{*}{$\mathrm{SED}^{1}$} & \multirow[b]{2}{*}{$P$-value } & \multicolumn{2}{|c|}{ Contrast } \\
\hline & 114 & 144 & 173 & & & Linear & Quadratic \\
\hline Live weight (kg) & $531.5^{\mathrm{b}}$ & $548.3^{\mathrm{a}}$ & $544.0^{\mathrm{a}}$ & 4.18 & $* * *$ & $* *$ & $* *$ \\
\hline Live weight gain $(\mathrm{kg} / \mathrm{d})$ & 0.16 & 0.27 & 0.24 & 0.193 & NS & NS & NS \\
\hline BCS & 2.38 & 2.41 & 2.37 & 0.030 & NS & NS & NS \\
\hline BCS change (units/wk) & -0.004 & 0.006 & 0.001 & 0.007 & NS & NS & NS \\
\hline ME requirement $(\mathrm{MJ} / \mathrm{d})$ & $191.3^{\mathrm{c}}$ & $222.3^{\mathrm{b}}$ & $242.3^{\mathrm{a}}$ & 6.34 & $* * *$ & $* * *$ & NS \\
\hline ME intake $(\mathrm{MJ} / \mathrm{d})$ & $204.2^{\mathrm{b}}$ & $222.8^{\mathrm{a}}$ & $231.0^{\mathrm{a}}$ & 4.54 & $* * *$ & $* * *$ & NS \\
\hline Daily energy status (MJ/d) & $12.78^{\mathrm{a}}$ & $0.539^{\mathrm{ab}}$ & $-11.05^{\mathrm{b}}$ & 6.20 & $* *$ & $* * *$ & NS \\
\hline Cumulative energy status (MJ) & $414^{\mathrm{a}}$ & $-537^{\mathrm{a}}$ & $-1,801^{\mathrm{b}}$ & 520 & $* * *$ & $* * *$ & NS \\
\hline
\end{tabular}

${ }^{\mathrm{a}-\mathrm{c}}$ Values within a row with no common superscript differ $(P<0.01)$.

${ }^{1} \mathrm{SED}=$ standard error of the difference.

NS, $P>0.05 ;{ }^{* *} P<0.01 ; * * * P<0.001$. 
Table 5. Effect of altering dietary protein concentration at d 151 of lactation on the efficiency of nitrogen use for milk production from d 1 to 150 and 151 to 305

\begin{tabular}{|c|c|c|c|c|c|c|c|c|}
\hline \multirow[b]{2}{*}{ Item } & \multicolumn{3}{|c|}{$\begin{array}{c}\text { Dietary CP concentration } \\
(\mathrm{g} / \mathrm{kg} \text { of } \mathrm{DM})\end{array}$} & & & \multirow[b]{2}{*}{$P$-value } & \multicolumn{2}{|c|}{ Contrast } \\
\hline & 114 & 144 & 173 & \multicolumn{2}{|c|}{$\mathrm{SED}^{1}$} & & Linear & Quadratic \\
\hline \multicolumn{9}{|l|}{ Day 1 to 150} \\
\hline Dietary nitrogen intake (kg) & $0.300^{\mathrm{c}}$ & $0.414^{\mathrm{b}}$ & $0.515^{\mathrm{a}}$ & 0.0 & & $* * *$ & $* * *$ & NS \\
\hline Milk nitrogen output (kg) & $0.126^{\mathrm{c}}$ & $0.160^{\mathrm{b}}$ & $0.179^{\mathrm{a}}$ & 0.0 & & $* * *$ & $* * *$ & $* * *$ \\
\hline \multirow[t]{3}{*}{ Efficiency of nitrogen use for milk production } & $0.423^{\mathrm{a}}$ & $0.391^{\mathrm{b}}$ & $0.350^{\mathrm{c}}$ & 0.0 & & $* * *$ & $* * *$ & NS \\
\hline & \multicolumn{6}{|c|}{ Dietary CP concentration $^{2}$} & & \\
\hline & $114 / 114$ & $144 / 144$ & $173 / 173$ & $114 / 144$ & $144 / 173$ & $173 / 144$ & SED & $P$-value \\
\hline Dietary nitrogen intake $(\mathrm{kg})$ & $0.307^{\mathrm{e}}$ & $0.411^{\mathrm{d}}$ & $0.535^{\mathrm{b}}$ & $0.414^{\mathrm{d}}$ & $0.545^{\mathrm{a}}$ & $0.433^{\mathrm{c}}$ & 0.0043 & $* * *$ \\
\hline Milk nitrogen output (kg) & $0.120^{\mathrm{d}}$ & $0.151^{\mathrm{b}}$ & $0.161^{\mathrm{a}}$ & $0.135^{\mathrm{c}}$ & $0.163^{\mathrm{a}}$ & $0.155^{\mathrm{b}}$ & 0.0025 & $* * *$ \\
\hline Efficiency of nitrogen use for milk production & $0.390^{\mathrm{a}}$ & $0.368^{\mathrm{b}}$ & $0.300^{\mathrm{d}}$ & $0.326^{\mathrm{c}}$ & $0.299^{\mathrm{d}}$ & $0.360^{\mathrm{b}}$ & 0.0049 & $* * *$ \\
\hline
\end{tabular}

${ }^{\mathrm{a}-\mathrm{e}}$ Values within a row with no common superscript differ $(P<0.001)$.

${ }^{1} \mathrm{SED}=$ standard error of the difference.

${ }^{2}$ The first value is the dietary $\mathrm{CP}$ concentration for $\mathrm{d} 1$ to 150 ; the second value is the $\mathrm{CP}$ concentration for $\mathrm{d} 151$ to 305

NS, $P>0.05 ; * * * P<0.001$.

$0.001)$, and fat plus protein yield $(P<0.001)$. Increasing dietary protein concentration from 144 to $173 \mathrm{~g} /$ $\mathrm{kg}$ of DM significantly increased DMI $(P<0.001)$, ME intake $(P<0.001)$, milk fat yield $(P<0.001)$, milk protein yield $(P<0.001)$, and fat plus protein yield $(P$ $<0.001)$. There was no significant effect $(P>0.05)$ of increasing dietary protein concentration from 144 to $173 \mathrm{~g} / \mathrm{kg}$ of DM on milk yield during the second half of lactation. Decreasing dietary protein concentration from 173 to $144 \mathrm{~g} / \mathrm{kg}$ of DM had no significant effect $(P$ $>0.05)$ on DMI, ME intake, milk yield, milk fat yield, milk protein yield, or fat plus protein yield. There was no significant effect $(P>0.05)$ of dietary protein change on the concentration of milk fat, protein, or lactose.

Data presented in Table 8 illustrates that increasing dietary protein concentration from 114 to $144 \mathrm{~g} / \mathrm{kg}$ of DM at d 151 of lactation significantly increased ME requirement $(P<0.001)$ and significantly decreased cumulative energy balance $(P<0.001)$, compared with animals that remain on $114 \mathrm{~g}$ of $\mathrm{CP} / \mathrm{kg}$ of $\mathrm{DM}$ throughout lactation. There was no significant effect $(P>0.05)$ of increasing dietary protein concentration from 114 to $144 \mathrm{~g} / \mathrm{kg}$ of $\mathrm{DM}$ on live weight or daily energy balance. An increase in the dietary protein concentration from 144 to $173 \mathrm{~g} / \mathrm{kg}$ of DM significantly increased live weight $(P<0.01)$, ME requirement $(P<$ $0.001)$, and daily energy balance $(P<0.01)$. There was no significant effect $(P>0.05)$ of altering the protein concentration of the diet from 144 to $173 \mathrm{~g} / \mathrm{kg}$ of DM on cumulative energy balance. Additionally, there was no significant effect $(P>0.05)$ of decreasing dietary protein concentration from 173 to $144 \mathrm{~g} / \mathrm{kg}$ of DM on live weight, ME requirement, daily energy balance, or cumulative energy balance. Dietary protein concentration had no significant effect on live weight change, BCS, or BCS change.

Table 6. Effects of dietary protein concentration on blood constituents of animals in early and mid lactation (1 to $150 \mathrm{~d})$

\begin{tabular}{|c|c|c|c|c|c|c|c|}
\hline \multirow[b]{2}{*}{ Blood parameter } & \multicolumn{3}{|c|}{ Dietary CP concentration ( $\mathrm{g} / \mathrm{kg}$ of $\mathrm{DM})$} & \multirow[b]{2}{*}{$\mathrm{SED}^{1}$} & \multirow[b]{2}{*}{$P$-value } & \multicolumn{2}{|c|}{ Contrast } \\
\hline & 114 & 144 & 173 & & & Linear & Quadratic \\
\hline Urea $(\mathrm{mmol} / \mathrm{L})$ & $1.56^{\mathrm{c}}$ & $2.59^{\mathrm{b}}$ & $4.32^{\mathrm{a}}$ & 0.130 & $* * *$ & $* * *$ & $* *$ \\
\hline Total protein $(\mathrm{g} / \mathrm{L})$ & $75.5^{\mathrm{c}}$ & $77.0^{\mathrm{b}}$ & $80.2^{\mathrm{a}}$ & 1.01 & $* * *$ & $* * *$ & NS \\
\hline Albumin $(\mathrm{g} / \mathrm{L})$ & $31.2^{\mathrm{b}}$ & $33.3^{\mathrm{a}}$ & $33.7^{\mathrm{a}}$ & 0.53 & $* * *$ & $* * *$ & NS \\
\hline Globulin $(\mathrm{g} / \mathrm{L})$ & 44.3 & 43.7 & 46.5 & 1.31 & NS & NS & NS \\
\hline NEFA $(\mathrm{mEq} / \mathrm{L})$ & 0.386 & 0.368 & 0.402 & 0.029 & NS & NS & NS \\
\hline $\operatorname{Leptin}^{2}(\mathrm{ng} / \mathrm{mL})$ & 1.97 & 2.04 & 2.00 & 0.352 & NS & NS & NS \\
\hline $\mathrm{IGF}_{-1}{ }^{2}(\mathrm{ng} / \mathrm{mL})$ & 103 & 103 & 99 & 6.5 & NS & NS & NS \\
\hline
\end{tabular}

\footnotetext{
${ }^{\mathrm{a}-\mathrm{c}}$ Values within a row with no common superscript differ $(P<0.05)$.

${ }^{1} \mathrm{SED}=$ standard error of the difference.

${ }^{2}$ IGF-1 samples ( $\mathrm{n}=24 ; 5$ time points), leptin samples $(\mathrm{n}=72 ; 8$ time points), and all other parameters $(\mathrm{n}=90 ; 16$ time points). NS, $P>0.05 ; * P<0.05 ;{ }^{* *} P<0.01 ; * * * P<0.001$
} 
Table 7. Effect of altering dietary protein concentration at d 151 of lactation on DMI, milk yield, milk constituents (fat, protein, and lactose) milk constituent yields (fat and protein), and milk energy output of animals from d 151 to 305

\begin{tabular}{|c|c|c|c|c|c|c|c|c|}
\hline \multirow[b]{2}{*}{ Item } & \multicolumn{6}{|c|}{ 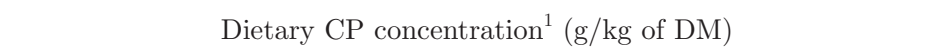 } & \multirow[b]{2}{*}{$\mathrm{SED}^{2}$} & \multirow[b]{2}{*}{$P$-value } \\
\hline & $114 / 114$ & $144 / 144$ & $173 / 173$ & $114 / 144$ & $144 / 173$ & $173 / 144$ & & \\
\hline DMI (kg/d) & $16.8^{\mathrm{d}}$ & $17.8^{\mathrm{c}}$ & $19.3^{\mathrm{ab}}$ & $18.0^{\mathrm{bc}}$ & $19.7^{\mathrm{a}}$ & $18.7^{\mathrm{b}}$ & 0.45 & $* * *$ \\
\hline Milk yield $(\mathrm{kg} / \mathrm{d})$ & $23.0^{\mathrm{c}}$ & $28.8^{\mathrm{a}}$ & $29.8^{\mathrm{a}}$ & $26.3^{\mathrm{b}}$ & $30.7^{\mathrm{a}}$ & $29.8^{\mathrm{a}}$ & 1.07 & $* * *$ \\
\hline \multicolumn{9}{|l|}{ Milk constituents $(\mathrm{g} / \mathrm{kg}$ ) } \\
\hline Fat & $42.3^{\mathrm{a}}$ & $38.3^{\mathrm{bc}}$ & $38.1^{\mathrm{bc}}$ & $42.7^{\mathrm{a}}$ & $39.8^{\mathrm{b}}$ & $37.4^{\mathrm{c}}$ & 0.99 & $* * *$ \\
\hline Protein & 33.2 & 33.5 & 33.7 & 32.6 & 33.7 & 33.5 & 0.60 & NS \\
\hline Fat & $0.97^{\mathrm{c}}$ & $1.10^{\mathrm{b}}$ & $1.13^{\mathrm{ab}}$ & $1.11^{\mathrm{b}}$ & $1.21^{\mathrm{a}}$ & $1.13^{\mathrm{ab}}$ & 0.046 & $* * *$ \\
\hline Protein & $0.76^{\mathrm{d}}$ & $0.94^{\mathrm{b}}$ & $1.03^{\mathrm{a}}$ & $0.86^{\mathrm{c}}$ & $1.04^{\mathrm{a}}$ & $0.99^{\mathrm{ab}}$ & 0.036 & $* * *$ \\
\hline Fat + protein & $1.93^{\mathrm{c}}$ & $2.20^{\mathrm{b}}$ & $2.25^{\mathrm{b}}$ & $2.21^{\mathrm{b}}$ & $2.43^{\mathrm{a}}$ & $2.27^{\mathrm{ab}}$ & 0.092 & $* * *$ \\
\hline Milk energy output $(\mathrm{MJ} / \mathrm{d})$ & $72.2^{\mathrm{c}}$ & $87.8^{\mathrm{ab}}$ & $89.5^{\mathrm{a}}$ & $81.7^{\mathrm{b}}$ & $94.8^{\mathrm{a}}$ & $89.1^{\mathrm{a}}$ & 3.57 & $* * *$ \\
\hline
\end{tabular}

${ }^{\mathrm{a}-\mathrm{d}}$ Values within a row with no common superscript differ $(P<0.05)$.

${ }^{1}$ The first value is the dietary CP concentration for $\mathrm{d} 1$ to 150 ; the second value is the $\mathrm{CP}$ concentration for d 151 to 305 .

${ }^{2} \mathrm{SED}=$ standard error of the difference.

NS, $P>0.05, * P<0.05 ; * * * P<0.001$.

Data presented in Table 5 indicate that the efficiency of nitrogen use for milk production was significantly $(P<0.001)$ greater in animals that were changed from 173 to $144 \mathrm{~g}$ of $\mathrm{CP} / \mathrm{kg}$ of $\mathrm{DM}$ at d 151 of lactation in comparison with those that remained on $173 \mathrm{~g}$ of $\mathrm{CP} /$ $\mathrm{kg}$ of DM throughout lactation.

The effects of changing dietary protein concentration at d 151 of lactation on blood parameters are presented in Table 9. Increasing the dietary $\mathrm{CP}$ concentration from 114 to $144 \mathrm{~g} / \mathrm{kg}$ of DM at d 151 of lactation significantly increased the concentrations of urea $(P<$ $0.001)$ and total protein $(P<0.01)$ from 151 to 305 DIM. Increasing the dietary concentration from 144 to $173 \mathrm{~g} / \mathrm{kg}$ of DM at d 151 of lactation significantly $(P<$ $0.001)$ increased the concentration of urea. Decreasing the dietary protein concentration from 173 to $144 \mathrm{~g} / \mathrm{kg}$ of DM at d 151 of lactation significantly $(P<0.001)$ decreased the concentration of urea.

\section{Production Responses from 1 to 305 DIM}

When evaluated over a full 305 d lactation, there were no significant $(P>0.05)$ differences in DMI, milk yield, milk fat concentration, milk fat yield, milk protein yield, milk fat plus protein yield, milk energy output, daily energy balance, or cumulative energy balance in animals receiving $173 \mathrm{~g}$ of $\mathrm{CP} / \mathrm{kg}$ of $\mathrm{DM}$ throughout lactation and those receiving $173 \mathrm{~g}$ of $\mathrm{CP} / \mathrm{kg}$ of $\mathrm{DM}$ from 1 to 150 DIM and $144 \mathrm{~g}$ of CP/ $\mathrm{kg}$ of DM from 151 to 305 DIM (Table 10). Animals receiving $144 \mathrm{~g}$ of CP/ $\mathrm{kg}$ of DM throughout lactation had significantly less $(P$ $<0.001)$ DMI than animals receiving $144 \mathrm{~g}$ of $\mathrm{CP} / \mathrm{kg}$ of DM from 1 to $150 \mathrm{DIM}$ and $173 \mathrm{~g}$ of $\mathrm{CP} / \mathrm{kg}$ of DM from 151 to 305 DIM (Table 10). However, there was no significant difference in milk yield, milk fat concentration, milk fat yield, milk protein yield, milk fat plus protein yield, milk energy output, daily energy balance,

Table 8. Effect of altering dietary protein concentration at d 151 of lactation on live weight, BCS, and body energy status of animals from d 151 to 305

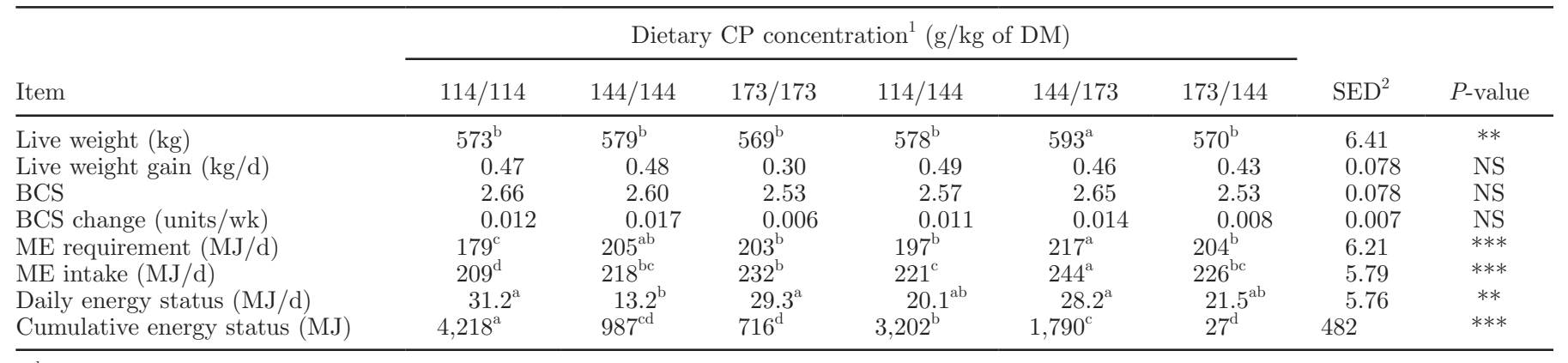

${ }^{\mathrm{a}-\mathrm{d}}$ Values within a row with no common superscript differ $(P<0.01)$.

${ }^{1}$ The first value is the dietary $\mathrm{CP}$ concentration for $\mathrm{d} 1$ to 150 ; the second value is the $\mathrm{CP}$ concentration for $\mathrm{d} 151$ to 305 .

${ }^{2} \mathrm{SED}=$ standard error of the difference.

NS, $P>0.05 ;{ }^{* *} P<0.01 ; * * * P<0.001$. 
Table 9. Effect of altering dietary protein concentration at d 151 of lactation on blood constituents of animals from d 151 to 305

Dietary CP concentration ${ }^{1}(\mathrm{~g} / \mathrm{kg}$ of DM)

\begin{tabular}{|c|c|c|c|c|c|c|c|c|}
\hline Item & $114 / 114$ & $144 / 144$ & $173 / 173$ & $114 / 144$ & $144 / 173$ & $173 / 144$ & $\mathrm{SED}^{2}$ & $P$-value \\
\hline Urea (mmol/L) & $2.06^{\mathrm{d}}$ & $3.29^{\mathrm{c}}$ & $5.43^{\mathrm{a}}$ & $3.43^{\mathrm{c}}$ & $5.13^{\mathrm{a}}$ & $4.16^{\mathrm{b}}$ & 0.303 & $* * *$ \\
\hline Total protein $(\mathrm{g} / \mathrm{L})$ & $77.2^{\mathrm{c}}$ & $80.2^{\mathrm{b}}$ & $82.6^{\mathrm{a}}$ & $80.4^{\mathrm{b}}$ & $79.0^{\mathrm{bc}}$ & $81.1^{\mathrm{ab}}$ & 1.45 & $* *$ \\
\hline Albumin $(\mathrm{g} / \mathrm{L})$ & 33.3 & 34.2 & 34.2 & 34.4 & 34.9 & 34.5 & 0.60 & NS \\
\hline Globulin (g/L) & 43.9 & 45.8 & 48.3 & 46.0 & 44.3 & 46.6 & 1.68 & NS \\
\hline NEFA (mEq/L) & 0.27 & 0.29 & 0.30 & 0.32 & 0.24 & 0.39 & 0.045 & $\mathrm{NS}$ \\
\hline $\mathrm{BHBA}(\mathrm{mmol} / \mathrm{L})$ & 0.55 & 0.51 & 0.47 & 0.53 & 0.53 & 0.51 & 0.50 & NS \\
\hline Glucose $(\mathrm{mmol} / \mathrm{L})$ & 3.31 & 3.20 & 3.32 & 3.30 & 3.26 & 3.23 & 0.078 & NS \\
\hline
\end{tabular}

${ }^{\mathrm{a}-\mathrm{d}}$ Values within a row with no common superscript differ $(P<0.01)$.

${ }^{1}$ The first value is the dietary $\mathrm{CP}$ concentration for $\mathrm{d} 1$ to 150 ; the second value is the $\mathrm{CP}$ concentration for $\mathrm{d} 151$ to 305 .

${ }^{2} \mathrm{SED}=$ standard error of the difference.

NS, $P>0.05 ; * * P<0.01 ; * * * P<0.001$.

or cumulative energy balance between these 2 groups. Animals receiving $114 \mathrm{~g}$ of $\mathrm{CP} / \mathrm{kg}$ of $\mathrm{DM}$ throughout lactation had a significantly $(P<0.001)$ greater daily energy balance and lesser milk yields, milk fat yields, milk protein yields, milk fat plus protein yield, and milk energy outputs than animals receiving $114 \mathrm{~g}$ of $\mathrm{CP} / \mathrm{kg}$ of DM from 1 to $150 \mathrm{DIM}$ and $144 \mathrm{~g}$ of $\mathrm{CP} / \mathrm{kg}$ of DM from 151 to 305 DIM (Table 10). There was no significant difference in DMI, milk fat concentration, or cumulative energy balance between these 2 groups.

\section{DISCUSSION}

\section{Dietary Protein Effects on Production Parameters}

Increasing dietary $\mathrm{CP}$ concentrations (1 to 150 DIM) from 114 to 144 and from 144 to $173 \mathrm{~g} / \mathrm{kg}$ of DM realized daily milk yield responses of 6.4 and 3.6 $\mathrm{kg} / \mathrm{d}$, respectively. Despite these differences suggesting a curvilinear relationship, results from an orthogonal contrast for linear and quadratic effects state that only a linear relationship exists (Table 3 ). These results are in contrast to previous authors who have demonstrated a quadratic relationship between milk output and dietary protein intake. Olmos Colmenero and Broderick (2006) reported an increase in milk yield, with increasing dietary $\mathrm{CP}$ concentration up to $165 \mathrm{~g} / \mathrm{kg}$ of $\mathrm{DM}$, after which point a decline in milk yield was noted. They also noted a similar pattern of increase in milk protein and fat yields. Furthermore, Cunningham et al. (1996) and Leonardi and Armentano (2003) observed no improvement in milk yield when dietary $\mathrm{CP}$ increased from 165 to $185 \mathrm{~g} / \mathrm{kg}$ of $\mathrm{DM}$ and from 161 to $189 \mathrm{~g} /$ $\mathrm{kg}$ of DM, respectively. In the present study, Figure 1 demonstrates a tendency toward a greater milk yield response when increasing dietary protein concentration

Table 10. Effect of altering dietary protein concentration at d 151 of lactation on DMI, milk yield, milk constituents (fat, protein, and lactose), milk constituent yields (fat and protein), milk energy output, and daily and cumulative energy balance of animals from d 1 to 305

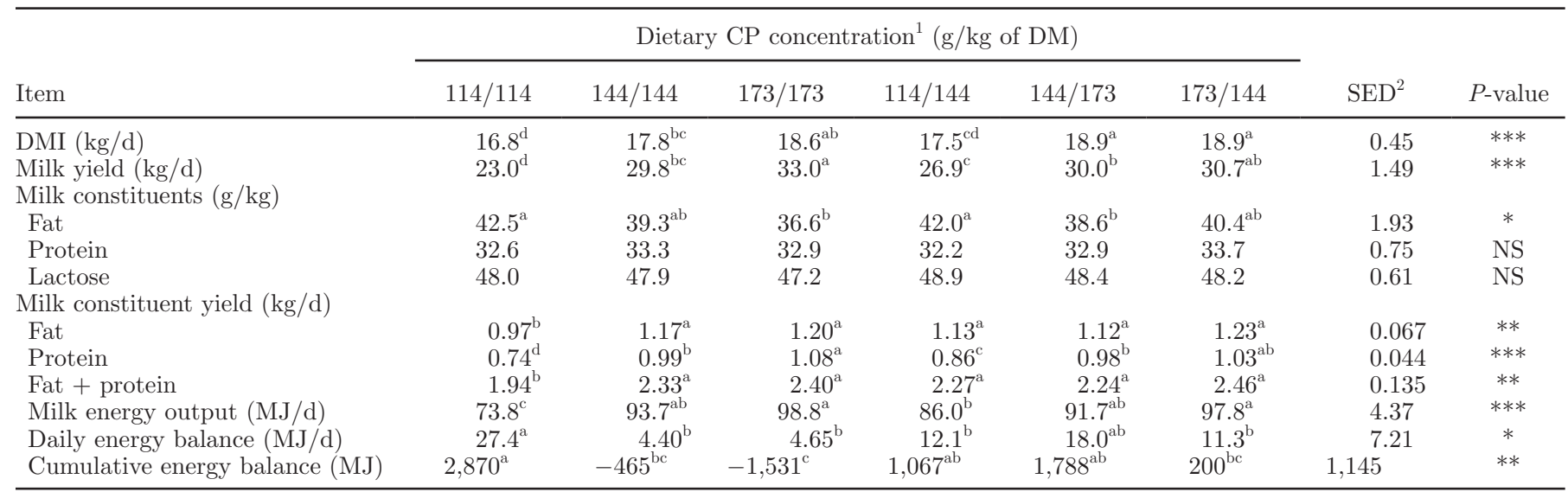

${ }^{\mathrm{a}-\mathrm{d}}$ Values within a row with no common superscript differ $(P<0.05)$.

${ }^{1}$ The first value is the dietary CP concentration for $\mathrm{d} 1$ to 150 ; the second value is the CP concentration for d 151 to 305 .

${ }^{2} \mathrm{SED}=$ standard error of the difference.

NS, $P>0.05 ;{ }^{*} P<0.05 ; * * * P<0.001$. 


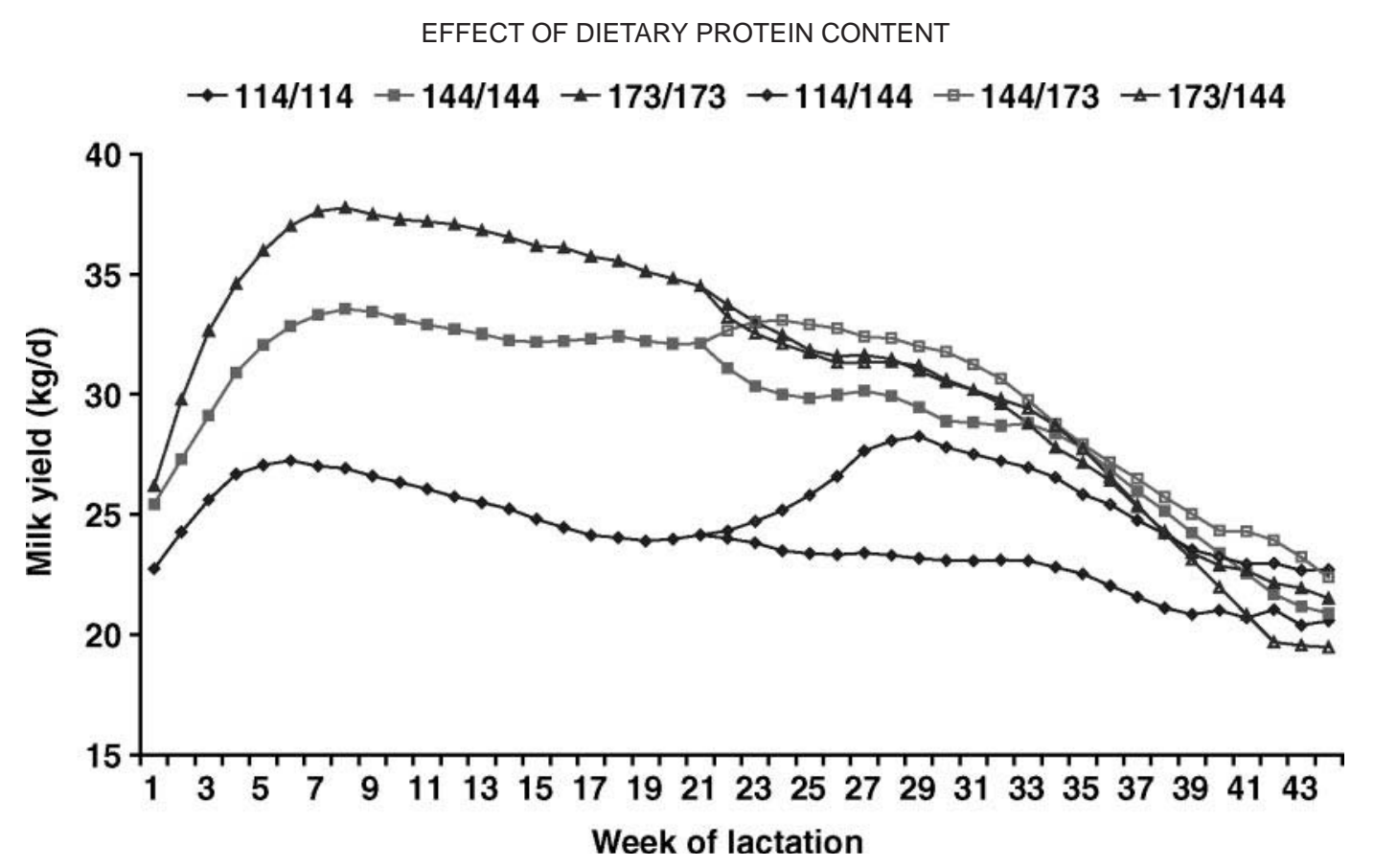
DIM).

Figure 1. Effect of dietary protein concentration on milk production (legend: dietary protein concentration, 1 to 150 DIM/151 to 305

from 114 to $144 \mathrm{~g} / \mathrm{kg}$ of DM than from 144 to $173 \mathrm{~g} / \mathrm{kg}$ of DM, especially in the early to mid lactation period. Figure 1 also indicates that post d 151 of lactation, there is a major decline in the efficiency of nitrogen utilization for milk production in animals allocated $173 \mathrm{~g}$ of $\mathrm{CP} / \mathrm{kg}$ of DM throughout lactation (1 to 305 DIM), compared with those allocated a reduced dietary $\mathrm{CP}$ concentration (173 to $144 \mathrm{~g} / \mathrm{kg}$ of $\mathrm{DM}$ ) at d 151 of lactation. Animals receiving $173 \mathrm{~g}$ of $\mathrm{CP} / \mathrm{kg}$ of $\mathrm{DM}$ before d 151 of lactation showed no detrimental effects on production when allocated $144 \mathrm{~g}$ of $\mathrm{CP} / \mathrm{kg}$ of $\mathrm{DM}$ at d 151 of lactation. These conclusions are verified in Table 5, which illustrates that the nitrogen efficiency significantly increases when animals are reduced from 173 to $144 \mathrm{~g}$ of $\mathrm{CP} / \mathrm{kg}$ of $\mathrm{DM}$ at d 151 of lactation.

Animals receiving $114 \mathrm{~g}$ of $\mathrm{CP} / \mathrm{kg}$ of $\mathrm{DM}$ had significantly higher milk fat concentrations in comparison to animals on $144 / 173 \mathrm{~g}$ of $\mathrm{CP} / \mathrm{kg}$ of DM during the first $150 \mathrm{~d}$ of lactation. However, orthogonal contrast for linear and quadratic effects identified a linear relationship between these 2 variables. These results are in contrast to those reported by Leonardi and Armentano (2003; 161 to $189 \mathrm{~g}$ of $\mathrm{CP} / \mathrm{kg}$ of $\mathrm{DM}$ ) and M'Hamed et al. (2001; 141 to $170 \mathrm{~g}$ of $\mathrm{CP} / \mathrm{kg}$ of $\mathrm{DM}$ ) who found that milk fat concentration increased in response to dietary CP. Additionally, Lundquist et al. (1986) found no effect of altering dietary protein concentration on milk fat content. The latter authors had similar protein levels to those used in the current experiment $(125,155$, and $180 \mathrm{~g}$ of $\mathrm{CP} / \mathrm{kg}$ of $\mathrm{DM})$. Total milk fat and protein yields increased with increasing dietary protein concentrations, which is in partial agreement with Broderick (2003). Broderick (2003) stated that yields of fat and protein increased with increases in the concentration of dietary CP from 151 to $167 \mathrm{~g} / \mathrm{kg}$ of DM but showed no further increase when dietary $\mathrm{CP}$ concentrations were increased to $184 \mathrm{~g} / \mathrm{kg}$ of DM. In the current experiment, a linear response was realized between milk fat yield and the concentration of dietary CP. When considering total milk protein yield, Leonardi and Armentano (2003) found that it was unaffected by an increase in dietary CP content (161 to $189 \mathrm{~g} / \mathrm{kg}$ of DM), with milk protein concentration decreasing. However, in the present study each increment in dietary $\mathrm{CP}$ produced a significant increase in milk protein yield; this relationship was curvilinear.

Broderick (2003) reported a linear increase in DMI with increases in dietary CP concentration from 152 to 167 and $183 \mathrm{~g} / \mathrm{kg}$ of DM. A linear relationship was also identified in the current study; however, there was no significant difference in DMI (1 to 150 DIM) between animals receiving 144 and those receiving $173 \mathrm{~g}$ of $\mathrm{CP} /$ $\mathrm{kg}$ of DM. If fermentable energy supply is not a limiting factor, then increasing the amount of eRDP should realize an increase in microbial protein synthesis and generate increased dietary intakes because of increased microbial activity in the rumen. In the present study, the eRDP concentration of diets containing 114, 144, and $173 \mathrm{~g}$ of $\mathrm{CP} / \mathrm{kg}$ of $\mathrm{DM}$ were predicted to be 75.5 , 94.5 , and $112.5 \mathrm{~g} / \mathrm{kg}$ of DM, respectively. However, di- 


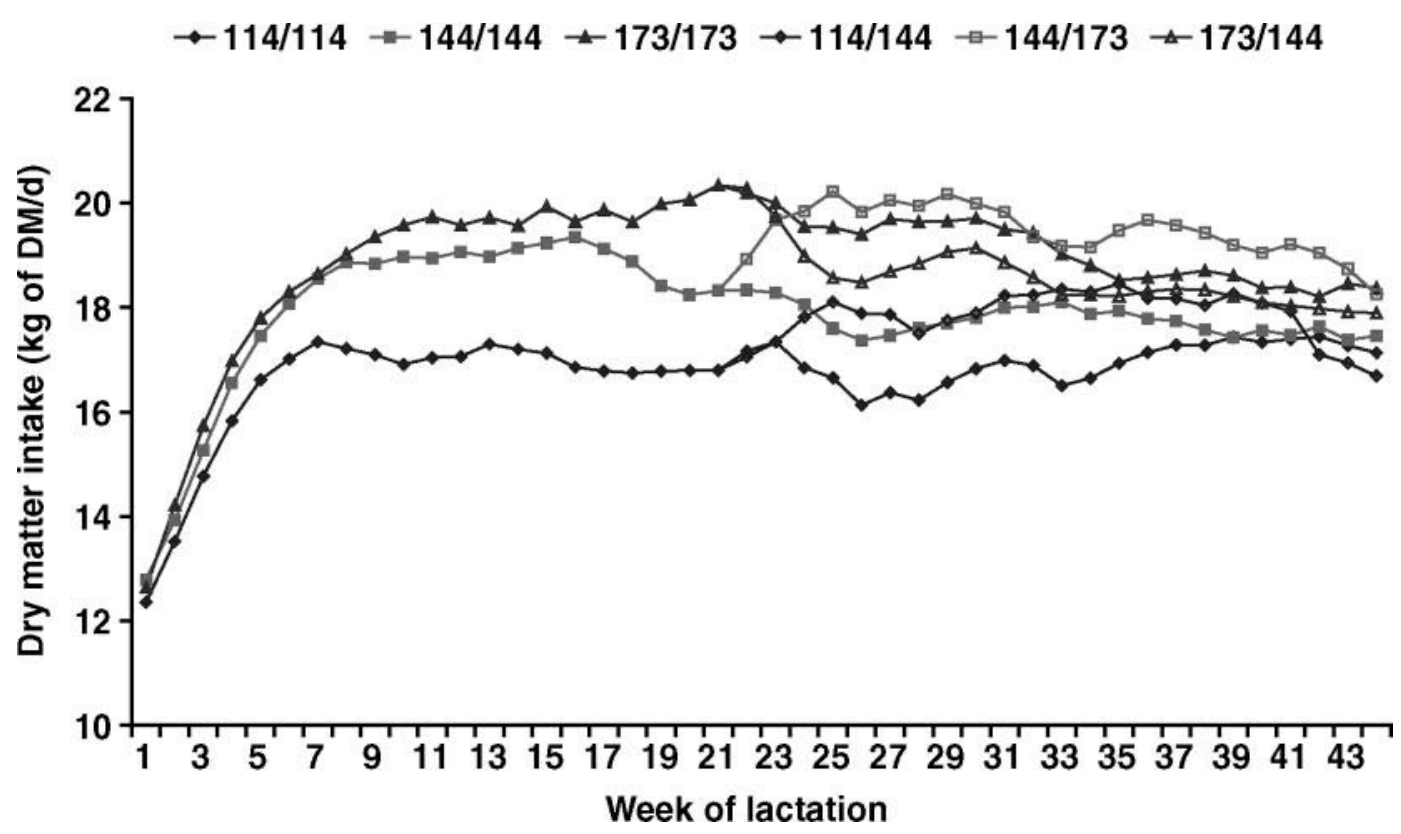

Figure 2. Effect of changing dietary protein concentration on DMI (legend: dietary protein concentration, 1 to 150 DIM/151 to 305 DIM).

etary intake responses were not in proportion to eRDP increments, which would suggest that either the supply of fermentable energy was limiting, or that bacterial growth was approaching a maximum. In agreement with this, Cunningham et al. (1996) found no significant difference in DMI when animals were offered 165 and 185 $\mathrm{g}$ of $\mathrm{CP} / \mathrm{kg}$ of DM. M'Hamed et al. (2001) concluded that increasing the protein content of the diet enhances DMI, milk yield, and BW gain, but that the responses vary greatly according to the type and level of protein supplementation.

Increasing dietary protein concentration from 114 to $173 \mathrm{~g} / \mathrm{kg}$ of DM significantly reduced the daily and cumulative energy balance. Increasing dietary protein concentration from 114 to $173 \mathrm{~g} / \mathrm{kg}$ of DM produced a $13.1 \%$ increase in ME intake but a $26.7 \%$ increase in ME requirement, which accounts for the decrease in daily energy balance. Additionally, an increase in dietary protein concentration from 114 to $173 \mathrm{~g} / \mathrm{kg}$ of DM significantly increased the interval to energy nadir. Animals that display a more negative energy balance will take longer to reach an energetic equilibrium (zero energy balance). Results presented in Table 4 indicate that the observed variation in cumulative energy balance between animals receiving 114 and $173 \mathrm{~g}$ of $\mathrm{CP} /$ $\mathrm{kg}$ of DM is not reflected in BCS change or live weight. A difference in cumulative energy balance of $2,215 \mathrm{MJ}$ (414 to -1,801) would equate to a difference in BCS of 1.25 units (1,770 MJ/unit BCS loss; AFRC, 1993), and a difference in live weight of $95 \mathrm{~kg}[23.4 \mathrm{MJ} / \mathrm{kg}$ of body live weight loss (AFRC, 1990)]. The actual dif- ference in BCS and live weight was 0.01 units and 12.5 $\mathrm{kg}$ (greater live weight in animals with more negative energy balance), respectively. These discrepancies may be partially a result of some basic assumptions used in the energy calculations. These assumptions include

1. The maintenance requirement of all animals is a constant value that is relative to metabolic BW, irrespective of the level of production.

2. The net efficiency of energy utilization for lactation $\left(\mathrm{k}_{\mathrm{l}}\right)$, despite being partially scaled to level of intake (Thomas, 2004), does not go below 0.59.

\section{Dietary Protein Effects on Blood Parameters (1 to 150 DIM)}

Plasma urea and total protein concentrations were significantly elevated by an increase in dietary protein content. Increased plasma urea concentrations indicate increased ammonia detoxification in the liver, whereas an increase in total blood protein concentrations indicate intestinal absorption of protein, which will be evident at greater dietary protein contents (where fermentable carbohydrate is not limiting). Increased ammonia concentrations in the blood may be caused by an oversupply of eRDP in the rumen (Kenny et al., 2001). The curvilinear relationship identified between urea and dietary CP concentration would support this suggestion. There was no significant effect of dietary protein content on plasma NEFA, glucose, or globulin concentrations, which is in agreement with results re- 


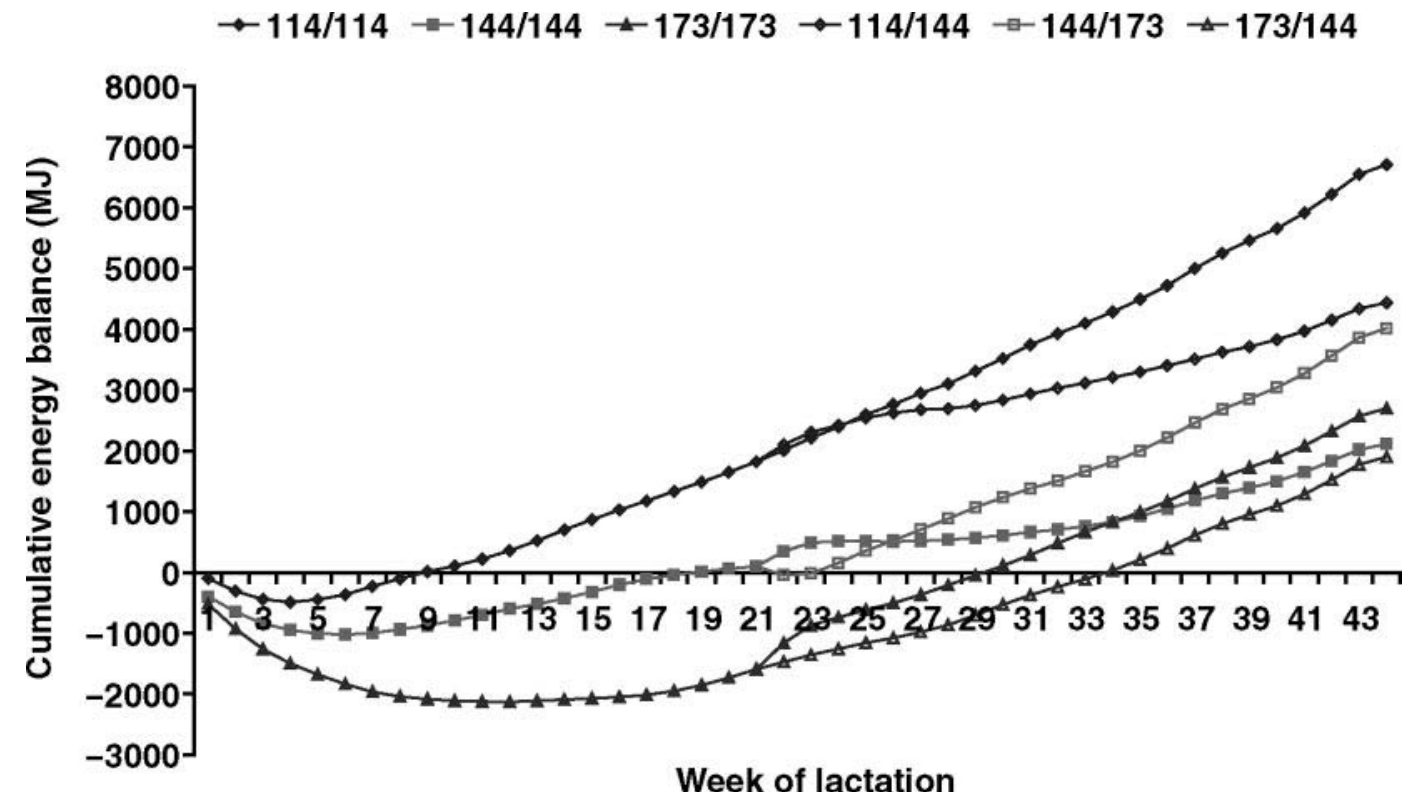

Figure 3. Effect of changing dietary protein concentration on cumulative energy balance (legend: dietary protein concentration, 1 to 150 DIM/151 to 305 DIM).

ported by M'Hamed et al. (2001). The latter authors showed no significant effects of increasing dietary protein concentration from 141 to $165 \mathrm{~g}$ of $\mathrm{CP} / \mathrm{kg}$ of DM on concentrations of these blood parameters. Additionally, there were no significant effects of altering the dietary protein content on serum leptin or IGF-1 concentrations. Adipose tissue is the biggest contributor to plasma leptin in ruminants (Chilliard et al., 2001) and is positively correlated with body condition (Kokkonen et al., 2005). As there were no significant effects of dietary CP concentration on BCS, or BCS change in the current study (Tables 4 and 8), no effects on leptin would be expected. Similarly, Armstrong et al. (2001) found no effect of dietary protein on plasma IGF-1 concentrations.

\section{Dietary Protein Effects on Production Parameters (151 to 305 DIM)}

Data presented in Figure 1 indicate that reducing the dietary protein concentration at d 151 of lactation from 173 to $144 \mathrm{~g} / \mathrm{kg}$ of DM had no detrimental effect on milk yield compared with animals that remained on $173 \mathrm{~g}$ of $\mathrm{CP} / \mathrm{kg}$ of DM (Table 7 ). This would imply that reducing the dietary protein concentration of the diet post 150 DIM is a key mitigation strategy to improve the efficiency of nitrogen use for milk production. Animals receiving $114 \mathrm{~g}$ of $\mathrm{CP} / \mathrm{kg}$ of $\mathrm{DM}$ from $\mathrm{d} 1$ to 150 of lactation displayed significant increases in milk yield when allocated $144 \mathrm{~g}$ of $\mathrm{CP} / \mathrm{kg}$ of $\mathrm{DM}$ during the second part of lactation (151 to 305 DIM). There was also a trend (though not significant, $P>0.05$ ) for an increase in milk yield of $1.9 \mathrm{~kg}$ per d (d 151 to 305) in animals changed from 144 to $173 \mathrm{~g}$ of $\mathrm{CP} / \mathrm{kg}$ of $\mathrm{DM}$ at d 151, compared with those that remained on $144 \mathrm{~g}$ of $\mathrm{CP} / \mathrm{kg}$ of $\mathrm{DM}$.

Increasing protein concentrations from 114 to 144 and 144 to $173 \mathrm{~g}$ of $\mathrm{CP} / \mathrm{kg}$ of $\mathrm{DM}$ at d 151 of lactation produced significant (Table 7; Figure 2) increases in DMI of 7.1 and $10.6 \%$, respectively (Figure 2). Reducing protein concentration from 173 to $144 \mathrm{~g}$ of $\mathrm{CP} /$ $\mathrm{kg}$ of DM tended $(P>0.05)$ to decrease DMI (Table 7). Therefore, increasing dietary protein concentration from 114 to $144 \mathrm{~g} / \mathrm{kg}$ of DM produced a $7.1 \%$ increase in ME intake but a $14.3 \%$ increase in milk yield, which resulted in a decrease in cumulative energy balance (Figure 3). Increasing dietary protein concentration from 144 to $173 \mathrm{~g} / \mathrm{kg}$ of DM produced a $10.6 \%$ increase in ME intake but a $6.5 \%$ increase in milk yield resulting in a significantly greater energy balance.

\section{CONCLUSIONS}

The present study assessed the effects of altering dietary protein concentration on production parameters of lactating dairy cows. The results indicate that in early lactation (d 1 to 150) an increase in dietary protein content up to $173 \mathrm{~g} / \mathrm{kg}$ of DM has beneficial effects on milk yield and DMI. However, in late lactation (151 to 305 DIM), more efficient use of dietary nitrogen can 
be achieved by feeding diets with lesser dietary protein concentrations (between 144 and $173 \mathrm{~g}$ of $\mathrm{CP} / \mathrm{kg}$ of $\mathrm{DM}$ ) without realizing detrimental effects on production. Improving efficiency and economic sustainability of dairy cow production systems, as well as reducing the environmental impact of intensive dairy farming is critical, and these results indicate that reducing dietary protein concentration in mid/late lactation improves the efficiency of use of dietary nitrogen with no detrimental effects on animal performance.

\section{ACKNOWLEDGMENTS}

Thanks are due to the technical staff at Agri-Food and Biosciences Institute Agriculture Branch, Hillsborough for their assistance in recording and preparing data sets. Assistance with analysis of blood samples at the Veterinary Sciences Division is greatly acknowledged. This study was cofunded by the Department of Agriculture and Rural Development and AgriSearch.

\section{REFERENCES}

Agricultural and Food Research Council (AFRC). 1990. Technical committee on responses to nutrients, report number 5, nutritive requirements of ruminant animals: Energy. Nutr. Abstr. Rev. 60:729-804. (Series B).

Agricultural and Food Research Council (AFRC). 1993. Energy and protein requirements of ruminants. CAB Int., Wallingford, UK.

Armstrong, D. G., T. G. McEvoy, G. Baxter, J. J. Robinson, C. O. Hogg, K. J. Woad, R. Webb, and K. D. Sinclair. 2001. Effect of dietary energy and protein on bovine follicular dynamics and embryo production in vitro: Associations with the ovarian insulinlike growth factor system. Biol. Reprod. 64:1624-1632.

Broderick, G. A. 2003. Effects of varying dietary protein and energy levels on the production of lactating dairy cows. J. Dairy Sci. 86:1370-1381.

Chase, L. E. 1994. Environmental considerations in developing dairy rations. Pages 56-62 in Proc. Cornell Nutr. Conf. Feed Manuf., Rochester, NY. Cornell Univ., Ithaca, NY.

Chilliard, Y., M. Bonnet, C. Delavaud, Y. Faulconnier, C. Lroux, J. Djiane, and F. Bocquier. 2001. Leptin in ruminants. Gene expression in adipose tissue and mammary gland, and regulation of plasma concentration. Domest. Anim. Endocrinol. 21:271-295.

Cunningham, K. D., M. J. Cecava, T. R. Johnson, and P. A. Ludden. 1996. Influence of source and amount of dietary protein on milk yield by cows in early lactation. J. Dairy Sci. 79:620-630.

Cushnahan, A., and F. J. Gordon. 1995. The effects of grass preservation on intake, digestibility and rumen degradation characteristics. Anim. Sci. 60:429-438.

Edmonson, A. J., I. J. Lean, L. D. Weaver, T. Farver, and G. Webster. 1989. A body condition scoring chart for Holstein dairy cows. J. Dairy Sci. 72:68-78.

Farm Animal Welfare Council (FAWC). 1997. Report on the welfare of dairy cattle. Farm Animal Welfare Council, Surrey, UK.
Hristov, A. N., R. P. Etter, J. K. Ropp, and K. L. Grandeen. 2004 Effect of dietary crude protein level and degradability on ruminal fermentation and nitrogen utilization in lactating dairy cows. J. Anim. Sci. 82:3219-3229.

Kenny, D. A., M. P. Boland, M. G. Diskin, and J. M. Sreenan. 2001. The effect of crude protein and fermentable carbohydrate intake on blood metabolite concentrations and fertility in beef heifers. Pages 323-329 in Fertility in the High-Producing Dairy Cow, Occasional Publications No. 26, Br. Soc. Anim. Sci., Edinburgh, UK.

Kokkonen, T., J. Taponen, T. Anttila, L. Syrjälä-Quist, C. Delavaud, Y. Chilliard, M. Tuori, and A. T. Tesfa. 2005. Effect of body fatness and glucogenic supplementation on lipid and protein mobilization and plasma leptin in dairy cows. J. Dairy Sci. 88:1127-1141.

Kung, L., Jr. 2000. Managing the high genetic merit cow. PhD Diss. Univ. Delaware, Newark.

Leonardi, C. M. S., and L. E. Armentano. 2003. Effect of two levels of crude protein and methionine supplementation on performance of dairy cows. J. Dairy Sci. 86:4033-4042.

Lundquist, R. G., D. E. Otterby, and J. G. Linn. 1986. Influence of formaldehyde-treated soybean meal on milk production. J. Dairy Sci. 69:1337-1345.

M'Hamed, D., P. Faverdin, and R. Verité. 2001. Effects of the level and source of dietary protein on intake and milk yield in dairy cows. Anim. Res. 50:205-211.

Olmos Colmenero, J. J., and G. A. Broderick. 2006. Effect of dietary crude protein concentration on milk production and nitrogen utilisation in lactating dairy cows. J. Dairy Sci. 89:1704-1712.

Park, R. S., R. E. Agnew, F. J. Gordon, and R. W. J. Steen. 1998. The use of near infrared reflectance spectroscopy (NIRS) on undried samples of grass silage to predict chemical composition and digestibility parameters. Anim. Feed Sci. Technol. 72:155-167.

Payne, R. W., P. W. Lane, P. G. N. Digby, S. A. Harding, P. K. Leech, G. W. Morgan, A. D. Todd, R. Thompson, G. Tunnicliffe Wilson, S. J. Welham, and R. P. White. 1993. GenStat 5 Release 3 Reference Manual. Oxford Sci. Publ., Oxford, UK.

Rodriguez, L. A., C. C. Stallings, J. H. Herbein, and M. L. McGilliard 1997. Effect of degradability of dietary protein and fat on ruminal, blood and milk components of Jersey and Holstein cows. J. Dairy Sci. 67:2354-2362

Roseler, D. K. 1994. Development and evaluation of feed intake and energy balance prediction models for lactating dairy cattle. $\mathrm{PhD}$ Diss. Cornell Univ., Ithaca, NY.

Steen, R. W. J. 1989. A comparison of soyabean, sunflower, and fish meals as protein supplements for yearling cattle offered grass silage based diets. Anim. Prod. 48:127-132.

Strang, B. D., S. J. Bertics, R. R. Grummer, and L. E. Armentano. 1998. Effect of long chain fatty acids on triglyceride accumulation, gluconeogenesis and ureagenesis in bovine hepatocytes. J. Dairy Sci. 81:728-739.

Thomas, C. 2004. Feed into milk: An advisory manual. Nottingham University Press, Nottingham, UK.

Wylie, A. R. G., D. M. B. Chestnut, and D. J. Kilpatrick. 1997. Growth and carcase characteristics of heavy slaughter weight lambs: Effects of sire breed and sex of lamb and relationships to serum metabolites and IGF-1. Anim. Sci. 64:309-318.

Yan, T., J. P. Frost, R. E. Agnew, R. C. Binnie, and C. S. Mayne. 2006. Relationships among manure nitrogen output and dietary and animal factors in lactating dairy cows. J. Dairy Sci. 89:39813991. 